\title{
Faktor-Faktor yang Memengaruhi Pemilihan Pinjaman dengan Sistem Rente di Desa Studi Kasus : Desa Panulisan Timur Kecamatan Dayeuhulur Kabupaten Cilacap
}

(Periode Tahun 2013-2014)

\section{Factors Influencing Selection of Loans with Rente System in Rural Community Case Study : Panulisan Timur District of Dayeuhluhur Regency of Cilacap (Time Period 2013-2014)}

\author{
Prawito Hudoro $^{1}$, Muhammad Findi A $^{2}$, Salahuddin El Ayyubi ${ }^{3}$ \\ ${ }^{1}$ Mahasiswa Ilmu Ekonomi, Program Studi Ekonomi Syariah Institut Pertanian Bogor, Email: \\ prawitohudoro@gmail.com \\ ${ }^{2}$ Dosen Ilmu Ekonomi, Fakultas Ekonomi dan Manajemen Institut Pertanian Bogor, Email: \\ muhammadfindi73@yahoo.com \\ ${ }^{3}$ Dosen Ekonomi Syariah, Fakultas Ekonomi dan Manajemen Institut Pertanian Bogor, Email: \\ 22djibran@gmail.com
}

\begin{abstract}
Rente loan system is a loan scheme that is based on interest. This loan system is widely used by the Micro and Small Medium Enterprises (SME) notably in particular rural communities. The purpose of this study is to analyze the development process and system received rents in the Panulisan Timur District of Dayeuhluhur Regency of Cilacap, and analyze the factors that affect the selection of loan seeking system. The method used in this study is a qualitative method with a case study approach. The data used is primary data obtained through observation and interviews to the villagers of the Panulisan Timur District of Dayeuhluhur Regency of Cilacap uses rente system. The study was conducted during the period December 2013 to April 2014. Number of key informants in this study were 5 people and the number of respondents 30 people. The results showed that the loan scheme growing rents in the Panulisan Timur District of Dayeuhluhur Regency of Cilacap consists of the active and passive processes. The existence of internal factors such as the need for cash is urgent and external factors in the form of an easy loan terms, the availability of funds every day, disbursement fast and easy access makes the transaction rents to survive and be accepted by society.
\end{abstract}

Keywords: Case studies, Financial systems, Islamic economics, Usurer.

Abstrak. Sistem pinjaman rente adalah salahsatu skema pinjaman yang berbasiskan bunga. Sistem pinjaman ini banyak digunakan oleh Usaha Kecil Mikro Menengah khususnya masyarakat pedesaan. Tujuan dari penelitian ini adalah menganalisis proses diterima dan berkembangnya sistem rente di masyarakat Desa Panulisan Timur Kecamatan Dayeuhluhur Kabupaten Cilacap, serta menganalisis faktor-faktor yang memengaruhi pemilihan pinjaman sistem rente. Metode yang digunakan dalam penelitian ini adalah metode kualitatif dengan pendekatan studi kasus. Data yang digunakan merupakan data primer yang diperoleh melalui observasi dan wawancara kepada masyarakat Desa Panulisan Timur Kecamatan Dayeuhluhur Kabupaten Cilacap yang menggunakan sistem rente, selama periode Desember 2013 hingga April 2014. Jumlah key informant dalam penelitian ini sebanyak 5 orang dan jumlah responden sebanyak 30 orang. Hasil penelitian menunjukkan bahwa skema pinjaman rente yang berkembang di Masyarakat Desa Panulisan Timur Kecamatan Dayeuhluhur Kabupaten Cilacap terdiri atas proses aktif dan proses pasif. Adanya faktor internal berupa keperluan uang cash yang mendesak dan faktor eksternal berupa syarat pinjaman yang mudah, ketersediaan dana setiap hari, pencairan dana cepat dan akses yang mudah menjadikan transaksi rente mampu bertahan dan diterima oleh masyarakat.

Kata kunci: ekonomi islam, rentenir, sistem pembiayaan, studi kasus. 


\section{Pendahuluan}

\subsection{Latar Belakang}

Pemikiran-pemikiran ekonomi telah muncul seiring dengan adanya peradaban-peradaban di dunia. Pemikiran-pemikiran ini diprediksi mulai terdokumentasi sejak ditemukannya tulisan pada peradaban India kuno, Mesir kuno, dan Babylonia. Salahsatu pemikiran ekonomi pada masa tersebut adalah kegiatan bisnisnya yang menggunakan sistem rente/bunga. Pakar Sejarah pemikiran ekonomi menyimpulkan bahwa transaksi keuangan dengan sistem rente telah ada dan berkembang sejak tahun 2500 sebelum masehi di Yunani kuno, Romawi kuno, dan Mesir kuno. Pada tahun 2000 sebelum masehi transaksi rente juga berkembang di Mesopotamia dan meluas hingga wilayah Babylonia pada tahun 500 sebelum masehi (Amalia 2010).

Praktek sistem rente di Indonesia sendiri terbukukan dalam sejarah yang dapat diketahui asal mulanya melalui prasasti di kota Medan pada tahun 1088 masehi. Prasasti yang ditemukan di wilayah Lobu Tua Barus ini berisi tentang sejarah keberadaan orang-orang India di Medan. Salahsatu penduduk India yang berada di Medan waktu itu adalah orang-orang Chetti atau Tjeti. Orang-orang Chetti ini memiliki keahlian dalam hal berdagang dengan sistem kredit, investasi dan juga sebagai rentenir (Harahap 2012).

Sejarah panjang keberadaan transaksi rente, ternyata masih ada sampai sekarang. Praktek rente dapat ditemui mulai dari masyarakat kota sampai dengan masyarakat desa. Desa Panulisan Timur Kecamatan Dayeuhluhur Kabupaten Cilacap adalah salah satu desa yang masih menggunakan sistem rente dalam transaksi keuangannya. Secara hukum positif transaksi rente ini memang tidak ada larangan ataupun sanksi tertulisnya. Berbeda halnya dengan norma agama dan norma masyarakat yang secara tegas tidak membenarkan adanya transaksi ini.

Transaksi rente secara etika kehidupan bermasyarakat, dianggap sebagai transaksi yang tidak diterima dan merupakan perbuatan yang tercela. Dalam bukunya "Laws" Plato (427-347 SM) mengutuk bunga dan memandangnya sebagai praktik yang zalim. Sebagai filsuf Yunani yang terkemuka pada masa itu, pemikiran Plato dapat dipandang cukup mewakili pandangan filsuf Yunani (Amalia 2010).

Dalam Islam, transaksi keuangan dengan sistem rente adalah salahsatu transaksi yang diharamkan. Larangan terhadap transaksi ini secara jelas Allah sampaikan dalam Al-Quran surah Ali-Imran ayat 130 yang artinya: Wahai orang-orang yang beriman! Janganlah kamu memakan Riba dengan berlipat ganda dan bertakwalah kamu kepada Allah supaya kamu mendapat keberuntungan.

Selain Islam, transaksi rente juga dianggap sebagai transaksi yang dilarang. Nasrani dalam Alkitabnya menyampaikan pada Imamat 25:36 Janganlah engkau mengambil bunga uang atau riba dari padanya, melainkan engkau harus takut akan Allahmu, supaya saudara-mu bisa hidup di antaramu.

Berdasarkan pandangan sosial dan agama, transaksi riba/rente merupakan bentuk transaksi yang ditentang dan dianggap menyimpang. Adanya aturan yang melarang serta pandangan yang buruk terkait transaksi rente, tidak menyebabkan transaksi ini hilang begitu saja. Seperti halnya Desa Panulisan Timur Kecamatan Dayeuhluhur Kabupaten Cilacap dimana 99\% penduduknya beragama Islam, masyarakatnya masih menggunakan transaksi rente dalam aktivitas ekonominya.

Keberadaan lembaga keuangan lain seperti Bank Umum Negeri, Bank Umum Swasta, Lembaga Keuangan Mikro ataupun Program Nasional Pemberdayaan Masyarakat (PNPM) masih belum 
secara total mampu menghilangkan keberadaan transaksi rente di Desa Panulisan Timur Kecamatan Dayeuhluhur Kabupaten Cilacap. Keunggulan yang ditawarkan oleh rentenir menjadikan transaksi ini masih terus berkembang hingga sekarang. Syarat yang mudah, ketersediaan dana setiap hari dan kemudahan akses menjadi salah satu keunggulan yang ditawarkan oleh rentenir. Berikut ini data Lembaga Keuangan terdekat dengan Desa Panulisan Timur Kecamatan Dayeuhluhur Kabupaten Cilacap:

Tabel 1 Lembaga Keuangan Terdekat dengan Desa Panulisan Timur

\begin{tabular}{llll}
\hline No & Jenis Lembaga Keuangan & Jumlah & $\begin{array}{l}\text { Jarak } \\
(\mathbf{k m})\end{array}$ \\
\hline 1. & Bank Syariah & 2 & 17 \\
\hline 2. & Bank Konvensional & 12 & $4-17$ \\
\hline 3. & Koperasi & 3 & $11-17$ \\
\hline 4. & BMT & 1 & 17 \\
\hline 5. & KUD & 1 & 11 \\
\hline 6. & PNPM & 1 & 3 \\
\hline
\end{tabular}

Sumber: data primer yang diolah

Adanya sisi negatif atau kekurangan sistem rente seperti penyitaan harta benda dan pertikaian dalam hubungan rumah tangga, belum mampu menghilangkan transaksi rente dari sistem ekonomi masyarakat Desa Panulisan Timur Kecamatan Dayeuhluhur Kabupaten Cilacap. Secara normatif, adanya efek negatif yang disebabkan oleh penggunaan transaksi rente, seharusnya dapat menyebabkan transaksi ini tidak lagi dipilih oleh masyarakat. Pada kenyataannya, transaksi ini masih berkembang dan digunakan oleh masyarakat.

Adanya ketidak sesuaian perilaku masyarakat yang masih memilih transaksi rente sedangkan disisi lain terdapat larangan dan efek negatifnya, menjadi latar belakang dilakukannya penelitian menganalisis faktor-faktor yang memengaruhi masyarakat Desa Panulisan Timur Kecamatan Dayeuhluhur Kabupaten Cilacap masih memilih menggunakan sistem rente pada transaksi keuangannya.

\subsection{Perumusan Masalah}

Aktivitas ekonomi menjadi sebuah aktivitas yang sangat vital dalam kehidupan masyarakat. Aktivitas ini diharapkan dapat berjalan selaras dengan norma agama dan masyarakat yang berlaku. Tapi dalam praktiknya aktivitas ini tidak selalu berjalan sesuai dengan norma yang ada (menyimpang). Salahsatu penyimpangan yang terjadi adalah masih digunakannya transaksi rente dalam aktivitas ekonomi masyarakat.

Desa Panulisan Timur Kecamatan Dayeuhluhur Kabupaten Cilacap merupakan desa mayoritas muslim. Sebesar 99\% penduduknya beragama Islam. Aktivitas keagamaan seperti kajian rutin sudah banyak dilakukan oleh masjid-masjid disetiap dusun. Dari kajian bulanan, mingguan, hingga harian sudah dilakukan oleh beberapa masjid. Akses menuju lembaga keuangan pemberi pinjaman modal seperti Bank Umum, Lembaga Keuangan Mikro (LKM) relatif terjangkau. Jarak yang perlu ditempuh untuk mengakses lembaga keuangan tersebut berkisar 4-5 kilometer.

Akses yang mudah menuju lembaga keuangan formal dan aktivitas keagamaan yang cukup padat masih belum dapat menggeser keberadaan rentenir di Desa Panulisan Timur Kecamatan Dayeuhluhur Kabupaten Cilacap. Hal tersebut menjadi sebuah masalah yang menjadikan perlu adanya penelitian yang mengkaji fenomena apa yang terjadi sehingga menyebabkan transaksi rente masih berkembang di Desa Panulisan Timur Kecamatan Dayeuhluhur Kabupaten Cilacap 
yang kemudian memberikan solusi berupa sistem baru yang sesuai dengan syariah dan dapat menggantikan sistem rentenir yang telah berkembang.

Berdasarkan uraian permasalahan diatas, perumusan masalah yang akan diteliti adalah sebagai berikut:

1. Bagaimana model rentenir yang berkembang di masyarakat Desa Panulisan Timur Kecamatan Dayeuhluhur Kabupaten Cilacap.

2. Bagaimana skema pinjaman rente terjadi dalam aktivitas ekonomi masyarakat Desa Panulisan Timur Kecamatan Dayeuhluhur Kabupaten Cilacap.

3. Faktor-faktor apa saja yang memengaruhi masyarakat Desa Panulisan Timur Kecamatan Dayeuhluhur Kabupaten Cilacap memilih sistem rente dalam aktivitas ekonominya.

\subsection{Tujuan Penelitian}

Berkaitan dengan perumusan masalah yang telah disampaikan maka tujuan penelitian ini antara lain:

1. Menganalisis model rentenir yang berkembang di masyarakat Desa Panulisan Timur Kecamatan Dayeuhluhur Kabupaten Cilacap.

2. Menganalisis skema pinjaman rente yang terjadi dalam aktivitas ekonomi masyarakat Desa Panulisan Timur Kecamatan Dayeuhluhur Kabupaten Cilacap.

3. Menganalisis faktor-faktor yang memengaruhi masyarakat Desa Panulisan Timur Kecamatan Dayeuhluhur Kabupaten Cilacap memilih sistem rente pada transaksi keuangannya.

\subsection{Manfaat Penelitian}

Hasil dari penulisan ini diharapkan dapat memberikan manfaat baik bagi peneliti ataupun bagi pihak-pihak lain yang berkepentingan, adapun manfaat tersebut antara lain adalah:

1. Bagi masyarakat

Dapat mengetahui alternatif pembiayaan syariah untuk menyelesaikan masalah keuangannya. Serta menghindari transaksi keuangan yang dilarang baik dari norma agama maupun norma masyarakat.

2. Bagi praktisi ekonomi syariah

Sebagai referensi bagi Lembaga Keuangan Syariah khususnya Lembaga Keuangan Mikro Syariah untuk mengetahui faktor-faktor yang menjadi penyebab masyarakat memilih sistem pembiayaan.

3. Pengambil Kebijakan

Sebagai referensi bagi pengambil kebijakan khususnya pengambil kebijakan di wilayah Desa Panulisan Timur untuk memberikan kebijakan dibidang ekonomi yang sesuai dengan syariah.

4. Bagi akademisi ekonomi Islam

Sebagai referensi bagi akademisi khususnya akademisi keuangan syariah untuk menyiapkan edukasi-edukasi yang sesuai dengan masyarakat desa dan sekaligus dapat menjadi acuan bagi peneliti selanjutnya.

5. Bagi Peneliti

Sarana untuk mengaplikasikan teori-teori ekonomi Islam yang didapatkan dalam perkuliahan, terutama teori ekonomi dalam hal pembiayaan syariah. Sebagai media bagi untuk menyebarkan ekonomi Islam melalui komunikasi langsung dengan warga. 


\subsection{Ruang Lingkup Penelitian}

Ruang lingkup penelitian ini difokuskan dengan mengkaji studi kasus transaksi keuangan yang dilakukan oleh masyarakat Desa Panulisan Timur Kecamatan Dayeuhluhur Kabupaten Cilacap. Transaksi yang dimaksudkan adalah transaksi yang berkaitan dengan pinjaman uang kepada rentenir. Hasil dari penelitian ini akan lebih menjelaskan fenomena yang terjadi pada sistem keuangan di Desa Panulisan Timur Kecamatan Dayeuhluhur Kabupaten Cilacap.

\section{Tinjauan Pustaka}

\subsection{Lembaga Keuangan Mikro}

Lembaga Keuangan Mikro (LKM) merupakan lembaga yang memberikan jasa keuangan terutama simpanan dan kredit kepada masyarakat kecil. Lembaga Keuangan Mikro terdiri atas dua jenis yaitu Lembaga Keuangan Mikro Formal dan Lembaga Keuangan Mikro non-Formal. Lembaga Keuangan Mikro Formal adalah lembaga keuangan mikro yang secara hukum positif diakui oleh hukum yang berlaku di Indonesia. Lembaga Keuangan Mikro non-Formal adalah lembaga keuangan mikro yang secara hukum positif tidak diakui oleh hukum yang berlaku di Indonesia namun keberadaannya diakui oleh masyarakat.

Lembaga Keuangan Mikro Formal sendiri dibagi menjadi Lembaga Keuangan Mikro Konvensional (berbasiskan bunga) dan Lembaga Keuangan Mikro Syariah (berbasiskan bagi hasil). Pada kasus yang terjadi di Desa Panulisan Timur Kecamatan Dayeuhluhur Kabupaten Cilacap Lembaga Keuangan Mikro yang saat ini banyak digunakan oleh masyarakat desa adalah Lembaga Keuangan Mikro non-formal. Lembaga Keuangan Mikro non-Formal yang ada di Desa Panulisan Timur Kecamatan Dayeuhluhur Kabupaten Cilacap saat ini adalah rentenir.

Agar bisa bertahan dan bersaing, Lembaga Keuangan Mikro (LKM) harus mampu beroprasi secara efisien. Lembaga Keuangan Mikro (LKM) secara tidak langsung harus berusaha menjadi lembaga yang terus menerus meningkatkan kinerja usahanya agar bisa bertahan dan bersaing di lingkungan masyarakat. Zeller dan Meyer (2002) mengemukakan bahwa indikator kinerja Lembaga Keuangan Mikro (LKM) dapat dikategorikan menjadi tiga yaitu, kesinambungan keuangan (Financial Sustainability), keterjangkauan (Outreach), dan dampak keberadaannya dalam sebuah lingkungan (Impact). Ketiga kategori tersebut selanjutnya disebut dengan segitiga keuangan mikro (The Triangle of Microfinance).

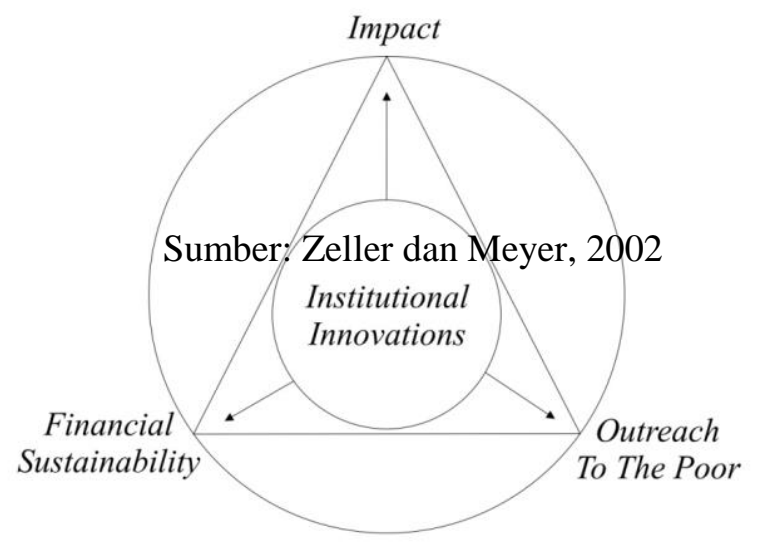

Gambar 1 Triangle of Microfinance 
Lembaga Keuangan Mikro (LKM) dalam memperluas outreach-nya ditentukan oleh kemampuan lembaga tersebut dalam menjaga financial sustainability. Sehingga Lembaga Keuangan Mikro (LKM) tersebut dapat memberikan Impact terhadap perkembangan ekonomi lingkungan sekitarnya. Ketiga indikator ini saling berkaitan satu sama lain, sehingga Lembaga Keuangan Mikro dapat dikatakan mampu bertahan dan bersaing jika telah memenuhi ketiga indikator tersebut.

Pada kenyataannya, untuk mencapai ketiga indikator tersebut dalam waktu yang bersamaan bukanlah perkara yang mudah. Sehingga yang dapat ditemui untuk Lembaga Keuangan Mikro (LKM) saat ini adalah keunggulan disalah satu indikatornya. Ketika salah satu indikator bisa terjaga dengan baik, maka indikator lainnya akan mudah untuk dibangun.

Dalam memilih lembaga pinjaman, perilaku masyarakat akan dipengaruhi oleh faktor internal dan eksternal. Hal ini seperti dinyatakan oleh Abraham Maslow yang disebut sebagai bapak Psikologi Humanitik bahwa Maslow menolak gagasan bahwa perilaku manusia dipengaruhi oleh faktor internal atau eksternal saja. Teori motivasi Maslow menyatakan bahwa perilaku manusia dikendalikan oleh kedua faktor tersebut yakni internal dan eksternal. Dorongan internal bersumber dari pribadi manusia berkaitan dengan faktor-faktor psikologis manusia. Sedangkan dorongan eksternal dipengaruhi oleh lingkungan masyarakat, lingkungan kerja atau keluarga (Juniarto 2013).

\subsection{Penelitian Terdahulu}

Puspitasari (2012) fokus penelitian mengenai akses UMKM terhadap pembiayaan mikro syariah dan dampaknya terhadap perkembangan keuntungan usaha dengan melakukan studi kasus BMT Tadbiirul Ummah, Kabupaten Bogor. Hasil penelitian menunjukkan bahwa akses rumah tangga responden kontrol pada lembaga keuangan memiliki nilai rata-rata simpanan dan pinjaman lebih besar pada lembaga keuangan formal (Bank). Variabel dummy jenis usaha, umur, omset usaha dan simpanan BMT merupakan faktor yang mempengaruhi akses BMT. Pembiayaan syariah meningkatkan keuntungan usaha pelaku usaha sebesar $6.21 \%$. Faktor-faktor yang mempengaruhi nilai perkembangan keuntungan UMKM adalah lama pendidikan, dummy jenis usaha 1 (perdagangan), lama usaha, total tenaga kerja, total aset, besarnya pembiayaan mikro syariah BMT dan besarnya kredit konvensional.

Supriatna (2003) fokus penelitian mengenai aksesibilitas petani kecil pada sumber kredit pertanian di tingkat desa: studi kasus petani padi di Nusa Tenggara Barat. Penelitian bersifat deskriptif, keragaan sumber kredit, aksesibilitas petani dan karakteristik skim kredit yang diharapkan petani diuraikan menurut hasil interpretasi data tabulasi. Hasil penelitian menunjukkan bahwa sumber-sumber dana tertua pada tingkat desa adalah kelembagaan informal, seperti Bank Harian, rentenir, pedagang beras, pedagang sarana produksi, dan penggilingan padi. Petani kecil dan petani tanpa tanah (penyakap) umumnya mengakses kelembagaan informal.

Skema kelembagaan informal menawarkan pinjaman pada tingkat bunga tinggi, tetapi sangat sesuai untuk petani kecil, seperti tanpa jaminan, prosedur sederhana, dan cepat realisasi. Sebaliknya petani kecil tidak dapat mengakses kelembagaan formal yang telah menyediakan pinjaman pada tingkat bunga rendah, karena antara lain: (a) mereka tidak memiliki suatu jaminan yang diperlukan oleh skema, terutama sertifikat tanah, (b) Pembayaran kembali kredit setiap bulan tidak sesuai untuk usaha tani padi yang memiliki siklus produksi musiman, dan (c) mereka tidak akrab dengan prosedur kredit yang berbelit-belit.

Oktavi (2009) fokus penelitian mengenai analisis faktor-faktor yang mempengaruhi pengambilan pembiayaan dan efektivitas pembiayaan usaha kecil pada Lembaga Keuangan 
Mikro Syariah (Studi Kasus: KJKS BMT Bina Umat Sejahtera, Lasem, Jawa Tengah). Penelitian ini menggunakan analisis regresi linier berganda. Hasil kesimpulannya adalah faktorfaktor yang memengaruhi secara signifikan pengambilan pembiayaan di KJKS BMT BUS Lasem adalah biaya peminjaman, jangka waktu angsuran, dan ada tidaknya agunan. Dari ketiga variabel yang memengaruhi pengambilan pembiayaan, yang paling besar pengaruhnya adalah biaya peminjaman. Efektivitas pembiayaan pada LKMS khususnya KJKS BMT BUS Lasem berdasarkan hasil penilaian responden dapat dikategorikan cukup efektif.

Pencapaian tujuan pembiayaan usaha kecil masih belum sepenuhnya tercapai, karena belum adanya dampak positif pembiayaan terhadap peningkatan pendapatan usaha anggota. Hal ini disebabkan besarnya pembiayaan yang diberikan tidak berpengaruh nyata terhadap peningkatan pendapatan. Tidak adanya pengaruh yang nyata terhadap perubahan pendapatan disebabkan oleh besarnya kebutuhan anggota yang harus dipenuhi sehingga pembiayaan yang diberikan hanya untuk menutupi modal yang dibutuhkan tetapi belum menyebabkan peningkatan pendapatan.

Widiyanto (2011) fokus penelitian mengenai efektivitas pembiayaan Qardh al-Hasan yang dilakukan oleh Baitul Mal Wat Tamwil untuk pengentasan kemiskinan. Metode yang digunakan yaitu metode regresi linear. Hasil dari pelaksanaan pembiayaan Qardh al-Hasan (yang telah dilakukan oleh BMT di daerah Jawa Tengah) menunjukkan bahwa mampu meningkatkan kinerja bisnis. signifikan yang ditunjukkan oleh kenaikan pendapatan bisnis mereka dan keuntungan disertai dengan peningkatan kemampuan pengusaha untuk memenuhi kebutuhan dasar, untuk membayar zakat dan sedekah, untuk menyimpan uang, membayar biaya sekolah untuk anak-anak mereka dan untuk membayar biaya pengobatan medis anggota rumah tangga.

Ananda (2011) fokus penelitian mengenai analisis perkembangan usaha mikro dan kecil setelah memperoleh pembiayaan mudharabah dari BMT At-Taqwa Halmahera di Semarang. Metode analisis data yang digunakan dalam penelitian ini meliputi uji validitas, uji reliabilitas dan uji pangkat tanda wilcoxon. Hasil kesimpulannya adalah terjadi peningkatan modal usaha sebesar 92\% setelah mendapatkan pembiayan dari BMT At Taqwa Halmahera Kota Semarang.

Kartono (2004) fokus penelitian mengenai analisis sosial ekonomi terhadap rentenir. Hasil penelitian menunjukkan rentenir memiliki peran mendukung ketersediaan dana yang bersifat kecil dan segera. Rentenir hidup dalam kehidupan sosial masyarakat bertahan-tahun sehingga keberadaannya dapat diterima oleh masyarakat.

Berdasarkan penelitian terdahulu dapat dilihat bahwa sistem rentenir telah membudaya dalam sistem ekonomi masyarakat. Dalam satu sisi, sistem rentenir memberikan manfaat berupa pencairan dana yang cepat untuk masyarakat. Disisi yang lain bunganya yang tinggi dan ketidak sesuaiannya dengan norma agama dan masyarakat perlu menjadi perhatian akademisi dan praktisi memberikan alternatif pembiayaan lain yang bisa menggantikannya.

Usaha untuk menggantikan sistem rente sudah dilakukan dibeberapa daerah dengan menggantikannya dengan sistem pembiayaan mikro syariah yang diwakili oleh BMT. Pada kasus yang terjadi di Kabupaten Bogor, BMT Tadbiirul Ummah telah mampu menunjukan dampak positif akan adanya pembiayaan syariah, kondisi perekonomian sekitar meningkat.

Penelitian ini bertujuan untuk mendeskripsikan sistem rentenir yang terjadi di Desa Panulisan Timur Kecamatan Dayeuhluhur Kabupaten Cilacap, menganalisis faktor-faktor yang memengaruhi masyarakat masih memilih pinjaman rente kemudian memberikan solusi untuk menggantikan sistem rentenir tersebut. Perbedaan penelitian ini dengan penelitian sebelumnya terletak pada metode yang digunakan adalah metode kualitatif, sedangkan pada penelitian terdahulu penelitian banyak menggunakan metode kuantitatif. Perbedaan lain terletak pada 
deskripsi hasil penelitian yang lebih banyak menjelaskan keunggulan sistem rente sehingga dapat diterima oleh masyarakat. Keunggulan yang dimiliki oleh sistem rente selanjutnya disarankan agar menjadi acuan bagi Lembaga Keuangan Mikro khususnya Lembaga Keuangan Mikro Syariah agar mampu memberikan keunggulan paling tidak setara dengan apa yang diberikan oleh rentenir kepada masyarakat.

\subsection{Kerangka Pemikiran}

Desa Panulisan Timur Kecamatan Dayeuhluhur Kabupaten Cilacap merupakan desa mayoritas muslim. Aktivitas keagamaan seperti kajian rutin sudah banyak dilakukan oleh masjid-masjid disetiap dusun. Akses menuju lembaga keuangan pemberi pinjaman modal seperti Bank Umum, Lembaga Keuangan Mikro (LKM) relatif terjangkau. Jarak yang perlu ditempuh untuk mengakses lembaga keuangan tersebut berkisar 4-5 kilometer.

Akses yang mudah menuju lembaga keuangan formal dan aktivitas keagamaan yang cukup padat, masih belum dapat menggeser keberadaan rentenir di Desa Panulisan Timur Kecamatan Dayeuhluhur Kabupaten Cilacap. Untuk mengetahui faktor-faktor yang menyebabkan sistem pembiayaan rente masih bertahan di Desa, maka dibuatlah kerangka berfikir untuk menemukan fenomena yang terjadi. Berikut ini kerangka berfikir yang dilakukan dalam melakukan penelitian ini:

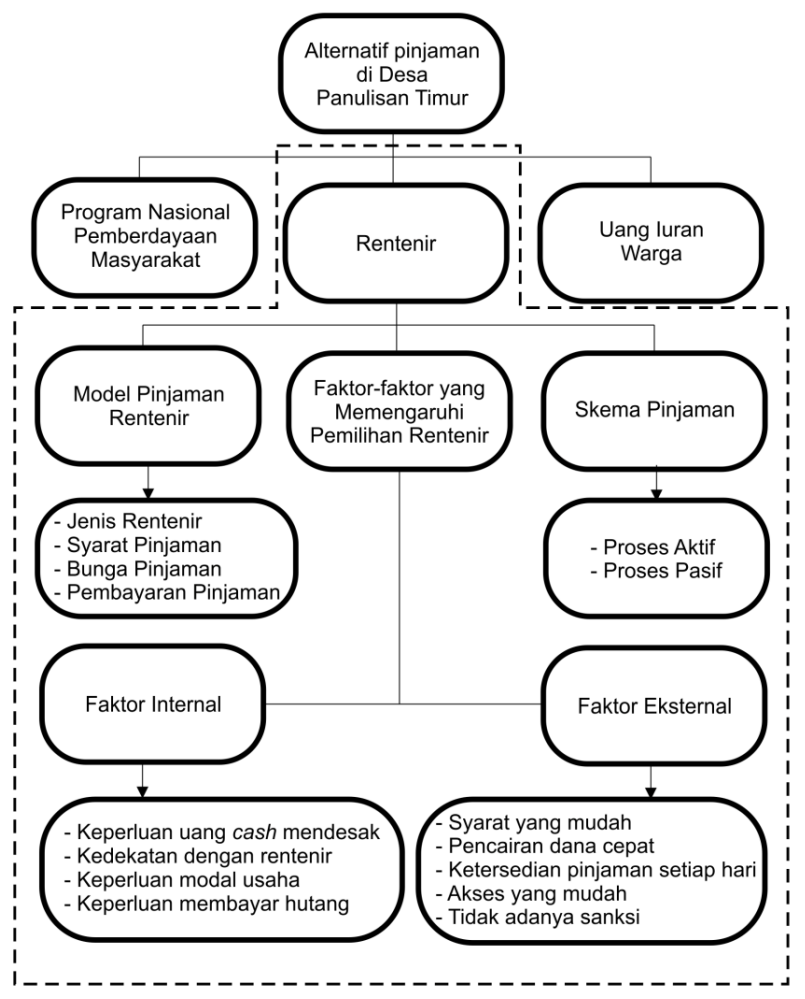

Gambar 2 Kerangka Berfikir

Keterangan :

: Alur analisis

: Bagian yang dianalisis 


\section{Metode Penelitian}

\subsection{Data Penelitian}

Data yang digunakan dalam penelitian ini adalah data primer dan data sekunder. Data primer diperoleh melalui tiga cara yaitu observasi, wawancara kepada masyarakat, dan triangulasi (pengecekan kebenaran). Observasi dilakukan sebagai upaya memahami lokasi penelitian dan memahami karakteristik masyarakat Desa Panulisan Timur Kecamatan Dayeuhluhur Kabupaten Cilacap. Wawancara dilakukan kepada key informant dan responden untuk mengetahui model rentenir yang berkembang, skema pinjaman rente dan mengetahui faktor-faktor yang memengaruhi dipilihnya sistem rente di masyarakat. Triangulasi dilakukan sebagai upaya pengecekan keabsahan informasi yang diberikan oleh key informant dan responden. Triangulasi dilakukan dengan membandingkan informasi yang diberikan oleh key informant dan responden dengan kondisi yang terjadi secara langsung di masyarakat. Data sekunder diperoleh dari data yang berasal dari pemerintahan setempat dan sumber pustaka lain yang mendukung.

\subsection{Waktu dan Tempat Penelitian}

Penelitian dilakukan di Desa Panulisan Timur Kecamatan Dayeuhluhur Kabupaten Cilacap selama periode Desember 2013 sampai April 2014. Wilayah penelitian mencakup 4 dusun yang berada di Desa Panulisan Timur. Dusun tersebut yaitu Dusun Cilubang, Dusun Cirungkun, Dusun Neglasari dan Dusun Ciawitali.

\subsection{Metode}

Metode yang digunakan dalam penelitian ini adalah metode kualitatif dengan pendekatan studi kasus. Pendekatan studi kasus adalah penelitian yang dilakukan untuk mengeksplorasi atau menjelaskan fenomena dalam konteks tertentu dengan berbagai macam sumber data (Baxter dan Jack 2008). Kasus yang diteliti adalah praktek rente yang terjadi di Desa Panulisan Timur Kecamatan Dayeuhluhur Kabupaten Cilacap.

Dalam penelitian ini yang digunakan sebagai subjek penelitian adalah key informant dan responden. Dalam bahasa Indonesia key informant dikenal dengan sebutan informan kunci. Dalam penelitian ini informan kunci memberikan informasi mendalam berkaitan dengan aktivitas rente yang terjadi di Desa Panulisan Timur Kecamatan Dayeuhluhur Kabupaten Cilacap. Sedangkan responden memberikan informasi terkait praktik rentenir dan faktor-faktor penyebab dipilihnya rentenir.

Key informant atau informan kunci dalam penelitian yaitu rentenir di wilayah desa Panulisan Timur, perangkat desa yaitu Kepala Bidang Hubungan Masyarakat (Humas), Ketua Rukun Warga dan ketua kelompok pinjaman Program Nasional Pemberdayaan Masyarakat Mandiri (PNPM-Mandiri) Desa Panulisan Timur Kecamatan Dayeuhluhur Kabupaten Cilacap. Responden dalam penelitian ini terdiri atas 30 orang warga yang dipilih dengan metode purposive sampling. Metode purposive sampling digunakan karena pertimbangan mencari karakteristik yang cocok dan memiliki keterlibatan secara langsung dengan aktivitas rente (Juanda 2009). Metode purposive sampling ini juga digunakan karena tidak adanya data jumlah populasi yang menggunakan pinjaman rente di Desa Panulisan Timur Kecamatan Dayeuhluhur Kabupaten Cilacap sehingga digunakan pengambilan sample dengan cara purposive sampling.

Selain pihak tersebut, untuk mendukung kelengkapan penelitian digunakan juga data sekunder yang berkaitan dengan kondisi wilayah Desa Panulisan Timur Kecamatan Dayeuhluhur Kabupaten Cilacap. Data sekunder diperoleh dari kantor Desa Panulisan Timur Kecamatan Dayeuhluhur Kabupaten Cilacap dan berbagai literatur-literatur yang mendukung. 


\subsection{Instrumen Penelitian}

Alat yang digunakan dalam mengumpulkan informasi berupa pedoman wawancara (interview guide), catatan lapang, recorder dan kamera. Pedoman wawancara terdiri atas dua bagian, yaitu pedoman wawancara untuk key informant dan pedoman wawancara untuk responden. Pedoman wawancara untuk key informant terdiri atas lima pokok pertanyaan. Bagian pertama berisi pertanyaan mengenai identitas key informant. Bagian kedua berisi pertanyaan mengenai fenomena aktivitas keuangan yang terjadi di masyarakat. Bagian ketiga berisi pertanyaan mengenai lembaga-lembaga penyedia jasa pinjaman modal di masyarakat. Bagian keempat berisi pertanyaan mengenai model rentenir dan skema pinjaman yang terjadi di masyarakat. Bagian kelima berisi pertanyaan mengenai kondisi-kondisi lingkungan berkaitan dengan aktivitas perekonomian yang terjadi di masyarakat. Pedoman wawancara kepada key informant ditampilkan pada tabel berikut:

Tabel 2 Pedoman Wawancara Key Informant

\begin{tabular}{ll}
\hline No & Lingkup Pertanyaan \\
\hline 1. & Identitas Key Informant \\
\hline 2. & Aktivitas Keuangan di Masyarakat \\
\hline 3. & Lembaga Penyedia Jasa Pinjaman Modal \\
\hline 4. & Model dan Skema Pinjaman Rentenir \\
\hline 5. & Kondisi lingkungan dan aktivitas masyarakat \\
\hline
\end{tabular}

Pedoman wawancara untuk responden terdiri atas lima pokok pertanyaan. Bagian pertama berisi pertanyaan-pertanyaan mengenai identitas dan aktivitas keuangan responden. Bagian kedua berisi pertanyaan-pertanyaan mengenai pemahaman responden terkait praktek rente dalam pandangan agama. Bagian ketiga berisi pertanyaan-pertanyaan mengenai model rentenir yang berkembang di masyarakat. Bagian keempat berisi pertanyaan-pertanyaan mengenai skema rentenir yang terjadi. Bagian kelima berisi pertanyaan-pertanyaan mengenai faktor-faktor yang memengaruhi responden memilih pinjaman dengan skema rente. Pedoman wawancara kepada responden ditampilkan pada tabel berikut:

Tabel 3 Pedoman Wawancara Responden

\begin{tabular}{ll}
\hline No & Lingkup Pertanyaan \\
\hline 1. & Identitas dan aktivitas keuangan \\
\hline 2. & Pemahaman agama terkait praktek rente \\
\hline 3. & Model rentenir yang berkembang di masyarakat \\
\hline 4. & Skema rentenir yang terjadi \\
\hline 5. & Faktor-faktor yang memengaruhi pemilihan rentenir \\
\hline
\end{tabular}

\subsection{Metode Pengolahan dan Analisis Data}

Data yang telah dikumpulkan dianalisis dengan cara deskriptif kemudian diolah dengan metode kualitatif model interaktif sebagaimana diajukan oleh Miles dan Huberman, yaitu terdiri atas tiga hal utama yaitu reduksi data, penyajian data, dan penarikan kesimpulan/verifikasi sebagai sesuatu yang saling berkaitan pada saat sebelum, selama, dan sesudah pengumpulan data dalam bentuk yang sejajar untuk membangun wawasan umum yang disebut analisis (Miles dan Huberman 1992).

Dengan mengetahui model rentenir yang berkembang, skema pinjaman rente yang terjadi dan faktor-faktor yang menyebabkan pinjaman rente diterima dalam aktivitas ekonomi masyarakat, maka hasil yang diperoleh disampaikan berupa implementasi hasil penelitian agar sistem rente 
tidak berkembang di masyarakat dan mengganti sistem tersebut dengan sistem pembiayaan yang sesuai dengan syariah Islam.

\section{Hasil dan Pembahasan}

\subsection{Gambaran Umum}

Lokasi Desa Panulisan Timur, merupakan salahsatu desa yang terletak di Kecamatan Dayeuhluhur Kabupaten Cilacap. Sebelah Utara berbatasan dengan Desa Ciwalen Kecamatan Dayeuhluhur, sebelah Timur berbatasan dengan Desa Madura Kecamatan Wanareja, sebelah Selatan berbatasan dengan Sungai Citanduy Kecamatan Dayeuhluhur, sebelah Barat berbatasan dengan Desa Panulisan Kecamatan Dayeuhluhur. Desa Panulisan Timur terletak di ujung Barat Kabupaten Cilacap yang secara langsung berbatasan dengan Kota Banjar Kabupaten Ciamis Provinsi Jawa Barat.

Berdasarkan pembagian luas wilayah sebagian besar wilayah Desa Panulisan Timur merupakan wilayah perkebunan. Sebesar $67 \%$ wilayah Desa Panulisan Timur merupakan daerah perkebunan. Perkebunan yang paling dominan adalah perkebunan karet. Sedangkan untuk pemukiman hanya $22 \%$ dari total lahan yang ada di Desa Panulisan Timur.

Sebagian besar penduduk Desa Panulisan Timur Kecamatan Dayeuhluhur Kabupaten Cilacap beragama Islam. Sebesar $99.56 \%$ penduduk beragama Islam dan $0.44 \%$ penduduknya beragama Kristen. Bangunan keagamaan terdiri atas 22 masjid, 4 mushala dan 1 gereja. Kegiatan keagamaan khususnya agama Islam yang paling rutin dilakukan adalah masjid Sabilittaqwa Dusun Cilubang. Masjid Sabilittaqwa ini mengadakan kajian rutin setiap hari setelah Ashar untuk anak-anak usia 4-16 tahun atau setara dengan anak usia Taman Kanak-kanak sampai Sekolah Menengah Pertama. Waktu setelah Maghrib sampai Isya kajian rutin remaja sampai lanjut usia. Selain kajian rutin setiap hari, terdapat juga kajian Mingguan yang khusus mengundang penceramah dari luar daerah. Waktu pelaksanaan pada hari Jumat, Minggu dan Rabu setelah shalat Duhur.

Sebesar 59\% penduduk Desa Panulisan Timur Kecamatan Dayeuhluhur Kabupaten Cilacap bermata pencaharian sebagai petani. Sebagian lain bermata pencaharian sebagai pegawai, buruh tani dan juga wiraswasta. Baik petani maupun wiraswasta kendala utama dalam menjalankan usaha mereka adalah ketersediaan modal. Petani, terkendala ketika musim tanam yang sering kekurangan modal, sedangkan wiraswasta sendiri terkendala ketika menjalankan usahanya tersebut.

Akses menuju lembaga pemberi pinjaman modal di Desa Panulisan Timur dapat dikatakan relatif terjangkau. Terdapat satu Bank cabang pembantu Bank Rakyat Indonesia (BRI) di wilayah Desa Panulisan Timur. Jarak tempuh menuju BRI tersebut berkisar 4-5 kilometer. Dengan biaya tertinggi yang perlu dikeluarkan Rp 20000 untuk perjalanan pulang dan pergi menuju bank. Selain lokasi tersebut terdapat lembaga keuangan lain yang bisa di akses dari Desa Panulisan Timur. Jarak yang perlu di tempuh berkisar 11 kilometer dan 17 kilometer. Untuk perbankan yang berjarak 11 kilometer biaya tertinggi yang perlu di keluarkan Rp 26000 sedangkan untuk perbankan yang berjarak 17 kilometer biaya tertinggi yang perlu dikeluarkan Rp 30000 .

Selain biaya transportasi tersebut, untuk memberikan pinjaman perbankan memiliki birokrasi lain yaitu melakukan pengecekan lokasi dan perlengkapan syarat-syarat seperti kartu suami istri, kartu keluarga, surat tanah dan surat usaha dari desa. Waktu yang diperlukan jika pinjaman disetujui adalah 1 minggu sampai 2 minggu. Uang pencairan dananya pun harus diambil secara langsung ke bank yang berkaitan. Biaya lain yang dikeluarkan adalah ketika melakukan cicilan 
pembayaran. Cicilan pembayaran dilakukan setiap bulan dan harus dibayarkan secara langsung ke bank yang bersangkutan. Biaya transportasi akan diperlukan kembali untuk melakukan cicilan pinjaman tersebut.

\subsection{Karakteristik Key Informant dan Responden}

Dalam penelitian ini sumber informasi utama berasal dari key informant atau informan kunci. Informan kunci memberikan informasi mengenai gambaran umum wilayah dan gambaran umum karakteristik masyarakat Desa Panulisan Timur Kecamatan Dayeuhluhur Kabupaten Cilacap. Informan kunci terdiri atas rentenir di wilayah desa Panulisan Timur, perangkat desa yaitu Kepala Bidang Hubungan Masyarakat (Humas), Ketua Rukun Warga dan ketua kelompok pinjaman Program Nasional Pemberdayaan Masyarakat Mandiri (PNPM-Mandiri) Desa Panulisan Timur Kecamatan Dayeuhluhur Kabupaten Cilacap. Karakteristik key informant ditampilkan dalam tabel sebagai berikut:

\section{Tabel 4 Karakteristik Key Informant}

\begin{tabular}{lll}
\hline No & Peran di Masyarakat & Jumlah \\
\hline 1. & Rentenir & 2 \\
\hline 2. & Ketua Bidang Humas & 1 \\
\hline 3. & Ketua Rukun Warga & 1 \\
\hline 4. & Ketua Kelompok PNPM & 1 \\
\hline \multicolumn{2}{l}{ Sumber: data primer yang diolah }
\end{tabular}

Responden berjumlah 30 orang yang terdiri atas laki-laki 13 orang dan perempuan 16 orang. Sebanyak 14 orang responden berprofesi sebagai petani sekaligus berwiraswasta, 5 orang responden berprofesi sebagai petani dan 11 orang yang berprofesi sebagai wiraswasta. Sebanyak 4 orang berusia 26-35 tahun, 8 orang berusia 36-45 tahun, 5 orang berusia 46-55 tahun, 11 orang berusia 56-65 dan 2 orang berusia 66-75 tahun.

\subsection{Model Pinjaman Rentenir}

\subsubsection{Jenis Rentenir}

Rentenir di Desa Panulisan Timur Kecamatan Dayeuhluhur Kabupaten Cilacap terdiri atas rentenir perorangan dan rentenir yang mengatasnamakan lembaga. Rentenir perorangan terdiri atas dua macam yaitu orang yang masih dalam lingkup Kecamatan Dayeuhluhur dan orang yang berada diluar kecamatan Dayeuhluhur. Rentenir yang merupakan warga Kecamatan Dayeuhluhur memiliki kedekatan lebih dengan nasabahnya. Proses pinjaman yang terjadi biasanya rentenir tidak secara langsung menawarkan pinjaman kepada calon nasabahnya, namun calon nasabah yang memerlukan yang secara langsung mengajukan peminjaman kepada rentenir. Rentenir perorangan yang berasal dari Kecamatan Dayeuhluhur biasanya tidak melakukan pencatatan secara khusus, pencatatan dilakukan sangat sederhana.

Rentenir yang berasal dari luar Kecamatan Dayeuhluhur biasanya disebut dengan istilah $S i$ Abang. Si Abang ini belum memiliki kedekatan sebelumnya dengan calon nasabah, sehingga untuk menawarkan jasa pinjaman rentenir ini biasanya menawarkan secara langsung jasa tersebut kepada calon nasabahnya. Dalam melakukan transaksinya Si Abang ini biasa melakukan pencatatan lebih rapi, dimana baik rentenir maupun nasabah diberikan kartu sebagai pencatatan jumlah pinjaman dan jumlah cicilan.

Selain dari rentenir perorangan ada juga rentenir yang mengatasnamakan lembaga. Warga Desa Panulisan Timur Kecamatan Dayeuhluhur Kabupaten Cilacap biasa menyebutnya dengan singkatan KoSiPa yang memiliki kepanjangan Koperasi Simpan Pinjam. KoSiPa biasanya 
belum memiliki kedekatan sebelumnya dengan calon nasabah, sehingga untuk menawarkan jasa pinjaman rentenir ini harus menawarkan jasa pinjaman secara langsung kepada calon nasabahnya. Dalam melakukan transaksinya KoSiPa ini biasa menggunakan pencatatan yang lebih rapi dibandingkan rentenir perorangan. KoSiPa biasa menggunakan buku catatan hutang dan juga kupon cicilan pembayaran pinjaman. Buku catatan hutang ini dipegang oleh rentenir kemudian kupon cicilan hutang akan dipegang oleh nasabah ketika melakukan cicilan pembayaran pinjaman.

\subsubsection{Syarat Pinjaman}

Dalam memberikan fasilitas pinjaman kepada para nasabah, rentenir memberikan syarat yang sangat mudah. Seperti yang disampaikan oleh salah satu responden. Beliau menyampaikan bahwa untuk melakukan pinjaman kepada rentenir syaratnya sangat mudah, "Syaratna KTP, bayarnamah kumaha engke" kata tersebut memiliki makna bahwa, syarat pinjaman cukup KTP masalah membayar cicilan bisa dipikirkan nanti. Bahkan jika sudah pinjam untuk selanjutnya tidak ada syarat-syarat lagi yang harus dipenuhi selain daripada membayar cicilan.

Rentenir perorangan yang masih merupakan warga Kecamatan Dayeuhluhur biasanya tidak memberikan syarat khusus kepada calon nasabahnya. Kepercayaan antar kedua belah pihak menjadi dasar dari pinjamannya dalam melakukan pinjaman cukup mengetahui lokasi rumah peminjam, setelah itu pinjaman sudah dapat dicairkan pada hari pinjaman diajukan. Syarat berupa KTP biasa digunakan oleh rentenir perorangan yang berasal dari luar Kecamatan Dayeuhluhur dan KoSiPa. Syarat lain yang dikatakan paling sulit yang diberikan oleh rentenir $\mathrm{Si}$ Abang dan KoSiPa yaitu melampirkan foto copy KTP dan foto copy Kartu Keluarga.

\subsubsection{Bunga Pinjaman}

Ada tiga cara membungakan uang yang dilakukan oleh rentenir di masyarakat Desa Panulisan Timur Kecamatan Dayeuhluhur Kabupaten Cilacap. Cara pertama bunga dibebankan setiap bulan hingga proses pinjaman berakhir, besaran bunga bersifat tetap berdasarkan pokok pinjaman awal. Contoh kasus jika ada pinjaman sebesar Rp 1000000 dan bunga yang ditetapkan adalah 10\% maka uang yang harus dikembalikan sebesar Rp 1100000 pada bulan kedua peminjaman. Dengan rincian Rp 1000000 pokok pinjaman dan Rp 100000 bunga pinjaman. Jika pokok pinjaman tidak dapat dilunasi pada bulan kedua, maka dibulan selanjutnya bunga pinjaman tetap harus dibayarkan sebesar Rp 100000 ditambah besar pokok yang belum terbayar. Sistem bunga seperti ini masih mengizinkan pokok pinjaman dibayar secara berangsur. Bunga pinjaman yang ditetapkan biasanya $10 \%$.

Pada kasus pinjaman di Desa Panulisan Timur Kecamatan Dayeuhluhur Kabupaten Cilacap ada salah satu nasabah yang melakukan pinjaman sebesar Rp 5000000 kepada rentenir. Besar bunga pinjaman yang dibebankan adalah 10\%, setelah 2 tahun tidak mampu melunasi pinjaman tersebut akhirnya tanah dan rumahnya disita oleh rentenir. Responden tersebut hanya menerima pengembalian sebesar Rp 1000000 dari hasil penjualan tanah dan rumahnya oleh rentenir. Sistem bunga seperti ini biasa dilakukan oleh rentenir perorangan yang berasal dari Kecamatan Dayeuhluhur.

Cara kedua bunga ditetapkan setiap bulan hingga proses pinjaman berakhir, persen bunga bersifat tetap berdasarkan pokok pinjaman ditambah bunga pinjaman jika pada bulan tersebut bunga pinjaman tidak dapat terbayar. Contoh, jika ada pinjaman sebesar Rp 1000000 dan bunga pinjaman 20\% maka uang yang harus dikembalikan diakhir bulan adalah Rp 1200000 dengan rincian $\quad \mathrm{Rp} 1000000$ pokok pinjaman dan Rp 200000 bunga pinjaman. Pokok pinjaman ini harus utuh dibayarkan sebesar Rp 1000000 tidak bisa diangsur. Ketika pokok pinjaman tidak dapat terbayar maka bunga pinjaman wajib dibayar pada akhir bulan. Jika diakhir bulan bunga pinjaman pun tidak dapat terbayar maka pada bulan selanjutnya bunga 
pinjaman sebesar $20 \%$ akan dikalikan dengan pokok pinjaman ditambah bunga pinjaman yang belum terbayar.

Pada kasus pinjaman di Desa Panulisan Timur Kecamatan Dayeuhluhur Kabupaten Cilacap ada salahsatu responden yang melakukan pinjaman sebesar Rp 2000000 kepada rentenir. Besar bunga pinjaman yang dibebankan adalah $20 \%$, setelah 4 bulan tidak mampu melunasi pinjaman tersebut akhirnya sepeda motor milik beliau disita oleh rentenir. Sistem bunga seperti ini biasa dilakukan oleh rentenir perorangan yang berasal dari Kecamatan Dayeuhluhur.

Cara ketiga bunga ditetapkan diawal pinjaman yang bersifat tetap satu kali selama periode pinjaman. Contoh, jika pinjaman sebesar Rp 1000000 dan bunga yang dibebankan adalah 20\% maka selama periode pinjaman orang yang meminjam harus membayar sebesar Rp 1200000.

Dalam menerapkan bunga pinjaman ini, rentenir biasanya tidak secara langsung menyampaikan persentase bunga di depan nasabah. Rentenir hanya menyampaikan jumlah pinjaman yang harus dikembalikan. Cicilan pinjaman tersebut biasanya dilakukan setiap hari atau sering juga disebut cicilan harian. Jumlah cicilan bervariasi bergantung dengan kebijakan dari rentenir. Rata-rata cicilan yang dilakukan adalah sebanyak 10 kali. Dari jumlah cicilan tersebut kita dapat menghitung bunga pinjamannya, sehingga secara tidak disadari bahwa bunga yang dibebankan untuk pinjaman tersebut rata-rata berkisar $2 \%$ per cicilan atau $55 \%$ per bulan.

Dalam kasus pembayaran kepada rentenir dengan cara ketiga ini, ternyata bunga tersebut bukanlah tambahan pinjaman akhir yang harus dibayar, pada kenyataannya masih ada biaya lain diluar dari bunga pinjaman yang dibebankan. Tambahan biaya tersebut sering disebut dengan biaya administrasi, besaran administrasi ini berbeda-beda setiap rentenirnya. Rata-rata biaya administrasi yang dibebankan oleh rentenir adalah $10 \%$ dari pinjaman. Sehingga total pengembalian yang ditanggung oleh setiap masyarakat yang meminjam kepada rentenir adalah lebih dari $55 \%$ per bulan.

Strategi tidak memunculkan persentase bunga di depan nasabah menjadikan bunga yang dibebankan oleh rentenir terlihat kecil, apalagi ketika nasabah yang menjadi objek rentenir tersebut merupakan masyarakat yang berasal dari pedesaan yang tidak terlalu paham mengenai besaran bunga yang dibebankan. Sistem bunga dengan cara ketiga ini biasa digunakan oleh rentenir perorangan yang berasal dari luar Kecamatan Dayeuhluhur atau disebut dengan $\mathrm{Si}$ Abang dan KoSiPa. Besaran bunga setiap pinjaman dapat dilihat di lampiran.

\subsubsection{Pembayaran Pinjaman}

Dalam melakukan pembayaran pinjaman, rentenir secara langsung mendatangi rumah nasabah yang melakukan pinjaman. Rentenir perorangan yang berasal dari Kecamatan Dayeuhluhur biasa melakukan penagihan cicilan sendiri tanpa menggunakan petugas-petugas khusus. Rentenir perorangan yang berasal dari luar Kecamatan Dayeuhluhur juga melakukan penagihan sendiri, tanpa menggunakan petugas-petugas khusus. Petugas-petugas khusus hanya digunakan oleh KoSiPa ketika melakukan penagihan cicilan pembayaran pinjaman.

Dari kedua jenis rentenir ini, yang paling banyak digunakan oleh warga Desa Panulisan Timur Kecamatan Dayeuhluhur Kabupaten Cilacap adalah rentenir yang mengatasnamakan lembaga atau sering disebut dengan KoSiPa dan rentenir yang sering disebut dengan istilah Si Abang. KoSiPa dan Si Abang juga banyak di pilih karena tidak adanya sanksi materi jika terjadi keterlambatan. Rentenir perorangan yang berasal dari dalam Kecamatan Dayeuhluhur jarang dipilih oleh warga karena bunganya yang dirasakan terlalu berlipat jika dibandingkan dengan KoSiPa. Dari segi pencairan dana rentenir perorangan dan rentenir lembaga memiliki kesamaan 
yaitu mampu memberikan dana cash dengan segera. Proses pencairan dana dapat diselesaikan dalam waktu 1-3 hari.

\subsection{Skema Pinjaman Rente}

Ada dua skema pinjaman yang terjadi pada praktik rente di Desa Panulisan Timur Kecamatan Dayeuhluhur Kabupaten Cilacap yaitu rentenir secara langsung menawarkan jasa pinjaman kepada calon nasabahnya selanjutnya skema ini disebut dengan proses aktif. Skema kedua rentenir tidak secara langsung menawarkan jasa pinjaman kepada calon nasabahnya, tapi calon nasabahnya yang secara langsung mengajukan pinjaman kepada rentenir skema ini selanjutnya disebut dengan proses pasif.

Proses aktif rentenir dimulai dari aktivitas rentenir yang datang ke warung-warung kecil untuk menawarkan jasa pinjaman. Pada tahap awal kunjungan kepada calon nasabahnya, rentenir biasanya melakukan transaksi jual beli terlebih dahulu dengan calon nasabahnya. Cara tersebut dilakukan untuk membangun kedekatan kepada calon nasabahnya. Tahap awal hanya dilakukan percakapan kecil terkait perkembangan usaha nasabahnya.

Pada tahap selanjutnya rentenir mulai masuk menawarkan jasa pinjaman modal kepada calon nasabahnya. Jasa pinjaman awal yang biasa ditawarkan oleh rentenir biasanya hanya berkisar Rp 100000 sampai Rp 200 000. Rentenir biasanya menawarkan pinjaman pertama tersebut dengan istilah percobaan. Tawaran pinjaman ini tidak selalu diterima baik oleh calon nasabahnya. Jawaban nasabah yang muncul ketika pertama kali ditawari oleh rentenir biasanya menolak. Ketika calon nasabahnya belum menerima tawaran untuk menerima pinjaman, rentenir akan datang dilain waktu dengan tujuan yang sama yaitu menawarkan pinjaman.

Intensitas berkunjung yang dilakukan oleh rentenir kepada calon nasabahnya, menjadikan kepercayaan muncul dari calon nasabah. Nasabah yang pada awalnya ragu dan takut untuk melakukan pinjaman, namun karena tawaran yang datang setiap hari akhirnya beberapa nasabah pun berani untuk mencoba melakukan pinjaman kepada rentenir.

Pada pinjaman awal yang dilakukan nasabah, rentenir biasanya memberikan syarat pinjaman berupa fotokopi KTP kepada nasabahnya. Pinjaman awal yang dilakukan oleh nasabah biasanya digunakan untuk keperluan menambah modal usahanya. Karena kemudahan sistem pembayaran yang diberikan oleh rentenir maka proses pembayaran cicilan pun sering berjalan dengan lancar. Pada tahap cicilan akhir setiap nasabah yang melakukan pinjaman kepada rentenir biasa ditawari kembali pinjaman baru. Pinjaman baru sebelum cicilan dibayar lunas ini biasa disebut dengan istilah "Ngabaru". Proses ngabaru ini biasanya berjalan tanpa pembebanan syarat apapun. Rentenir secara langsung memberikan pinjaman tanpa ada syarat berupa fotokopi KTP.

Tawaran untuk memperpanjang pinjaman dengan Ngabaru tidak selalu diterima oleh setiap nasabah, ada yang langsung menolak tawaran tersebut namun ada juga yang menerima tawaran untuk ngabaru tersebut. Pembayaran yang dianggap ringan dan syarat yang semakin mudah menjadikan nasabah berani untuk mencoba melakukan pinjaman kembali kepada rentenir. Pada tahap pinjaman kedua dan seterusnya tidak semua nasabah melakukan pinjaman dengan alasan menambah modal lagi, terkadang keperluan uang cash yang mendesak dan juga keperluan konsumtif menjadi latar belakang peminjaman uang kepada rentenir.

Proses aktif dominan terjadi pada model rentenir KoSiPa dan juga Si Abang. Proses aktif diterimanya sistem rente ini menjadi sebuah siklus yang terus ada di masyarakat Desa Panulisan Timur Kecamatan Dayeuhluhur Kabupaten Cilacap. Siklus ini selanjutnya dijadikan model proses aktif skema pinjaman rente. Model tersebut digambarkan dalam sebuah diagram alur sebagai berikut: 


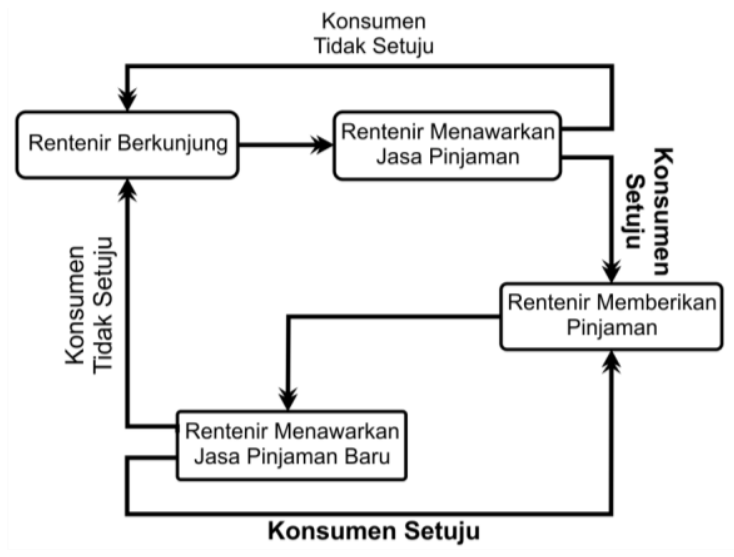

\section{Gambar 3 Proses Aktif Pinjaman Rentenir}

Berbeda halnya dengan proses aktif, proses pasif ini biasa terjadi pada rentenir perorangan yang berasal dari Kecamatan Dayeuhluhur. Pada proses ini rentenir tidak secara langsung menawarkan pinjaman kepada calon nasabahnya, tapi calon nasabahnya yang secara langsung mengajukan pinjaman kepada rentenir. Proses pasif ini biasa terjadi pada rentenir perorangan yang berasal dari Kecamatan Dayeuhluhur dan juga pada KoSiPa dan Si Abang yang telah bertransaksi bertahan-tahun di Desa Panulisan Timur.

Proses pasif diterimanya rentenir di masyarakat Desa Panulisan Timur Kecamatan Dayeuhluhur Kabupaten Cilacap biasa terjadi pada masyarakat yang memerlukan uang cash segera. Masyarakat yang memerlukan uang cash segera biasanya akan mencari informasi kepada tetangga lain yang pernah melakukan pinjaman kepada rentenir.

Setelah terjadi komunikasi dengan rentenir, maka pinjaman pun dilakukan. Ketika pinjaman dilakukan kepada KoSiPa atau kepada Si Abang, maka pada tahap akhir cicilan nasabah akan ditawari kembali untuk melakukan tambahan pinjaman. Tambahan pinjaman ini disebut dengan istilah "Ngabaru". Tawaran yang diberikan oleh rentenir biasanya tidak secara langsung diterima oleh nasabah. Ada nasabah yang menerima tawaran untuk ngabaru, ada juga nasabah yang menolak tawaran tersebut.

Nasabah yang tidak menerima tawaran untuk ngabaru secara tidak langsung telah menjadi aset pasif rentenir. Aset pasif yang dimaksud adalah suatu ketika jika nasabah tersebut memerlukan lagi pinjaman mendesak, maka kemungkinan besar rentenir tersebut yang akan diminta bantuan untuk memenuhi kebutuhan keuangannya.

Proses pasif diterimanya sistem rente di masyarakat terjadi membentuk sebuah siklus yang tidak terputus. Siklus tersebut selanjutnya dijadikan model proses pasif skema pinjaman rente. Proses pasif skema pinjaman rente ini digambarkan dalam sebuah diagram alur sebagai berikut: 


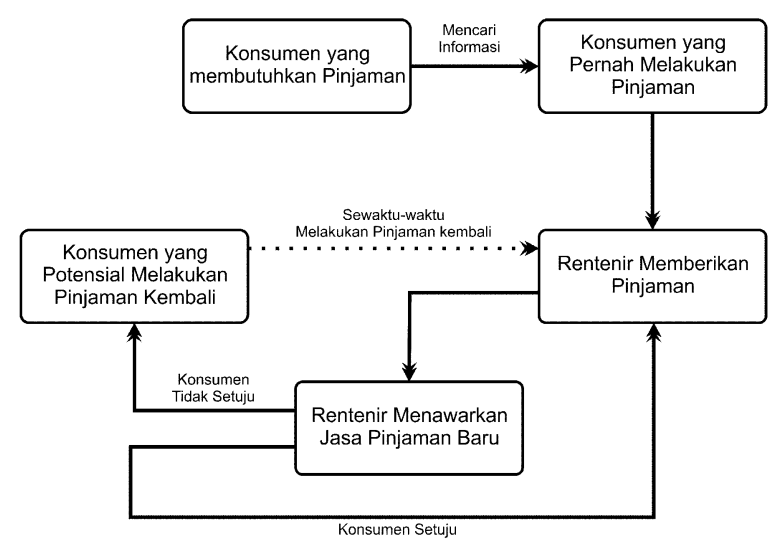

Gambar 4 Proses Pasif Pinjaman Rentenir

\subsection{Faktor-faktor yang Memengaruhi Pemilihan Sistem Rente}

Dalam mengambil keputusan untuk menerima atau menolak sebuah pinjaman, masyarakat Desa Panulisan Timur Kecamatan Dayeuhluhur Kabupaten Cilacap dipengaruhi oleh dua faktor yaitu faktor internal dan faktor eksternal. Faktor Internal adalah faktor yang muncul dari dalam diri masyarakat, baik itu berupa dorongan untuk memilih, maupun menolak sistem rente dalam aktivitas ekonominya. Faktor Eksternal adalah faktor yang muncul dari luar diri subjek, baik itu yang berasal dari rentenir secara langsung maupun dari lingkungan sekitar yang mendukung. Faktor ini dapat berupa dorongan untuk memilih, maupun menolak sistem rente dalam aktivitas ekonominya. Dalam kasus yang terjadi di Desa Panulisan Timur Kecamatan Dayeuhluhur Kabupaten Cilacap faktor internal yang memengaruhi pemilihan sistem rente yaitu:

Tabel 5 Faktor-faktor internal

\begin{tabular}{lll}
\hline No & \multicolumn{1}{c}{ Faktor Internal } & $\begin{array}{c}\text { Jumlah Responden } \\
(\mathbf{\%})\end{array}$ \\
\hline 1. & Keperluan uang cash mendesak & 83 \\
\hline 2. & Kedekatan dengan rentenir & 3 \\
\hline 3. & Keperluan modal usaha & 50 \\
\hline 4. & Keperluan membayar hutang-hutang lain & 47 \\
\hline
\end{tabular}

Sumber: data primer yang diolah

Alasan memilih pinjaman rentenir yang paling dominan adalah karena faktor internal berupa keperluan uang cash yang mendesak. Sebesar $83 \%$ responden menyatakan bahwa alasan dipilihnya pinjaman rentenir adalah karena keperluan uang cash yang mendesak. Pada kasus di Desa Panulisan Timur Kecamatan Dayeuhluhur Kabupaten Cilacap alternatif pinjaman untuk memenuhi keperluan uang cash yang mendesak hanya mungkin diberikan oleh rentenir. Lembaga formal lain tidak ada yang mampu memberikan pinjaman untuk keperluan uang cash mendesak.

Pada kasus yang terjadi di Desa Panulisan Timur, Keperluan uang cash yang mendesak yaitu keperluan untuk berobat, keperluan untuk membayar biaya sekolah anak dan biaya untuk keperluan konsumsi sehari-hari. Seperti yang terjadi pada salahsatu responden, beliau memiliki penyakit batu empedu. Untuk melakukan perawatan beliau harus melakukan pengecekan sekaligus pengobatan setiap minggu. Untuk memenuhi kebutuhan pembayaran obat dan transportasi yang begitu rutin, beliau tidak mampu hanya mengandalkan penghasilannya dari berjualan sehingga cara termudah untuk memenuhi kebutuhan uang cash beliau, dilakukanlah pinjaman kepada rentenir. Melakukan pinjaman kepada rentenir dapat dikatakan sangat mudah, jika beliau mengajukan pinjaman pada malam hari, keesokan harinya pinjaman sudah dapat 
diterima sehingga untuk mengatasi masalah keuangan yang berhubungan dengan keperluan mendesak untuk berobat beliau sering menggunakan jasa rentenir.

Kedekatan dengan rentenir yang dimaksud adalah adanya hubungan personal antar nasabah dengan rentenir baik itu keluarga ataupun tetangga. Pada kasus yang terjadi pada responden seorang pengrajin kursi, beliau memiliki tetangga yang bekerja di tempat peminjaman uang atau sering disebut $\mathrm{KoSiPa}$. Setiap hari, tetangganya tersebut sering menawarkan jasa pinjaman kepada KoSiPa. Alasan yang diberikan adalah untuk silaturahim agar semakin dekat dan sering berkunjung. Responden tersebut akhirnya mau menerima pinjaman karena merasa tidak enak dengan tetangganya, beliau berfikir sama-sama mencari kerja harus saling membantu, apalagi itu tetangga yang dikenal. Hubungan personal tersebut yang menjadikan alasan dilakukannya pinjaman kepada rentenir.

Keperluan modal usaha yaitu keperluan dana cash untuk mendirikan atau melanjutkan usaha. Pada Kasus yang terjadi di Desa Panulisan Timur, keperluan modal ini biasa terjadi pada sektor usaha wiraswasta. Seperti yang terjadi kepada salahsatu responden yaitu seorang pedagang keliling di wilayah Dusun Cilubang, beliau berjualan untuk membantu perekonomian keluarga. Penghasilan suami sebagai buruh perkebunan dirasakan belum cukup untuk memenuhi kebutuhan keluarga dengan dua orang anak sehingga beliau menjadi pedagang keliling. Untuk memulai usaha beliau, mengandalkan penghasilan suami masih belum cukup sehingga beliau melakukan pinjaman kepada tetangga. Pinjaman kepada tetangga ini sering kali menimbulkan masalah kerukunan dikarenakan jika terjadi keterlambatan membayar, sering terjadi pertikaian kecil antar tetangga. Hal tersebut menjadikan beliau menghindari meminjam kepada tetangga. Sehingga hal termudah yang dilakukan beliau adalah dengan meminjam kepada rentenir.

Keperluan membayar hutang-hutang lain yaitu adanya keperluan uang cash untuk membayar hutang-hutangnya kepada orang atau lembaga lain. Pada kasus yang terjadi di Desa Panulisan Timur, salahsatu responden mengalami kendala dalam membayar kepada rentenir-rentenir. Hutang pinjaman kepada rentenir meskipun sedikit secara nominal namun karena banyak rentenir yang di pinjam maka sering terjadi penagihan pada hari yang bersamaan. Jika penghasilan warung beliau tidak mencukupi untuk membayar hutang-hutang kepada rentenir maka cara termudah yang dilakukan beliau adalah dengan meminjam lagi kepada rentenir lain. Dalam kasus yang terjadi di Desa Panulisan Timur Kecamatan Dayeuhluhur Kabupaten Cilacap faktor eksternal yang memengaruhi pemilihan sistem rente yaitu:

Tabel 6 Faktor-faktor eksternal

\begin{tabular}{lll}
\hline No & \multicolumn{1}{c}{ Faktor Eksternal } & $\begin{array}{c}\text { Jumlah Responden } \\
(\mathbf{\%})\end{array}$ \\
\hline 1. & Syarat yang mudah & 100 \\
\hline 2. & Pencairan dana cepat & 100 \\
\hline 3. & Ketersediaan pinjaman setiap hari & 100 \\
\hline 4. & Akses yang mudah & 100 \\
\hline 5. & Tidak adanya sanksi & 90 \\
\hline
\end{tabular}

Sumber: data primer yang diolah

Keunggulan yang ditawarkan oleh rentenir adalah adanya syarat yang mudah, pencairan dana cepat, ketersediaan pinjaman setiap hari, akses yang mudah menjadi faktor yang sangat kuat untuk menarik masyarakat meminjam kepada rentenir. Sebesar $100 \%$ responden menyatakan faktor tersebut merupakan keuntungan yang diberikan oleh rentenir.

Pada kasus yang terjadi di Desa Panulisan Timur Kecamatan Dayeuhluhur Kabupaten Cilacap, yang dimaksud dengan syarat yang mudah adalah dokumen-dokumen yang diperlukan untuk 
melakukan pinjaman tidak banyak. Dokumen yang diperlukan hanya fotokopi KTP kalau pun ada hanya fotokopi KTP dan Kartu Keluarga. Pencairan dana cepat yaitu proses untuk mendapatkan pinjaman dana tidak memerlukan waktu berhari-hari, waktu yang diperlukan untuk mencairkan dana biasanya langsung pada hari dimana pinjaman diajukan ataupun paling lama proses tersebut berlangsung 2 sampai 3 hari, hal tersebut disebabkan karena pengajuan pinjaman dilakukan pada hari libur atau pada sore hari. Ketersediaan pinjaman setiap hari yaitu nasabah bisa mengajukan dana setiap hari kepada rentenir. Hal ini dikarenakan rentenir melakukan kunjungan kepada nasabah hampir setiap hari, kecuali hari libur. Akses yang mudah yaitu nasabah tidak perlu mengeluarkan biaya yang besar untuk melakukan pinjaman kepada rentenir. Nasabah cukup menghubungi rentenir melalui nasabah lain atau menghubungi melalui pesan singkat kepada rentenir. Kemudahan untuk mengajukan pinjaman dengan biaya yang kecil ini selanjutnya disebut dengan akses yang mudah. Tidak adanya sanksi yaitu rentenir tidak memberlakukan sanksi materi kepada nasabah. Rentenir hanya memberikan teguran kepada nasabahnya yang melakukan keterlambatan.

Selain pengaruh faktor internal dan eksternal, berdasarkan observasi dalam penelitian, diperoleh data bahwa terdapat tiga faktor lain yang dapat memengaruhi keputusan masyarakat Desa Panulisan Timur dalam memilih sistem pinjaman rente. Faktor tersebut adalah pendidikan formal, pendidikan agama dan tidak adanya alternatif pembiayaan lain yang sesuai dengan syariah.

Faktor pendidikan formal memiliki peran membentuk pemikiran rasional dari masyarakat tentang berlakukanya sistem bunga. Dari hasil observasi diperoleh data bahwa penerapan bunga dalam setiap pinjaman telah diajarkan sejak bangku Sekolah Dasar. Secara tidak langsung pendidikan formal ini akan melatih pemahaman masyarakat bahwa memberikan pinjaman dengan kelebihan bunga merupakan suatu hal yang wajar. Sehingga ketika transaksi keuangan di masyarakat menggunakan sistem bunga, maka masyarakat merasa hal tersebut merupakan sesuatu hal yang wajar.

Faktor pendidikan agama seharusnya dapat berperan memberikan pemahaman terhadap larangan bunga. Pada praktek yang terjadi di Desa Panulisan Timur, pendidikan agama yang khusus membahas materi muamalah berkaitan dengan riba belum ada. Seharusnya pemahaman agama dapat membentuk mental masyarakat untuk menghadirkan rasa takut untuk menjalankan transaksi dengan sistem bunga. Dengan adanya pemahaman larangan riba ini masyarakat seharusnya tidak lagi menggunakan transaksi rente dalam kesehariannya.

Tidak adanya alternatif pembiayaan syariah memiliki peran yang besar dalam penentuan keputusan masyarakat memilih pinjaman. Pada kasus yang terjadi di Desa Panulisan Timur, Bank Syariah atau lembaga keuangan syariah mikro seperti Baitul Maal Wat Tamil (BMT) belum ada. Sehingga masyarakat tidak memiliki alternatif lain untuk melakukan pinjaman.

\subsection{Implikasi Hasil Penelitian}

Berdasarkan hasil penelitian, solusi yang dapat dilakukan untuk masyarakat Desa Panulisan Timur Kecamatan Dayeuhluhur Kabupaten Cilacap dalam menghilangkan transaksi rente adalah dengan adanya kerjasama antara pemerintahan setempat, pengurus masjid (ulama), akademisi dan praktisi ekonomi Islam. Permasalahan keuangan masyarakat Desa Panulisan Timur, terutama yang berkaitan dengan transaksi rente dapat diselesaikan dengan memberikan solusi berupa pengaktifan fungsi infaq masjid. Maksud dari mengaktifkan fungsi infaq masjid adalah dengan menggunakan dana infaq masjid sebagai dana produktif untuk kemaslahatan masyarakat Desa Panulisan Timur. Untuk merealisasikan pengelolaan dana infaq masjid tersebut, masjid dapat mendirikan Lembaga Keuangan Mikro Syariah (LKMS) berjenis koperasi syariah atau Baitul Maal Wat Tamwil (BMT) dengan berbasiskan masjid sebagai kantornya. Sehingga secara 
hukum formal, keberadaan pengelolaan dana infaq dapat dinaungi oleh payung hukum.

Ketika ada masyarakat yang mendapatkan masalah berupa keperluan uang cash yang mendesak, maka berkaitan dengan hal darurat tersebut pihak BMT masjid harus mampu mendefinisikan keperluan mendesak tersebut. Ketika keperluan tersebut untuk berobat atau keperluan darurat lain yang berkaitan dengan nyawa, maka BMT masjid seharusnya dapat menggunakan dana infaq-nya untuk membantu masyarakat memberikan pinjaman uang. Pinjaman tersebut dapat menggunakan skema pinjaman tidak berbunga (qordul hasan). Dimana masyarakat hanya memiliki kewajiban untuk membayar pokok pinjamannya saja.

Sedangkan untuk keperluan lain yang bersifat konsumtif atau usaha, masjid dapat melakukan kerjasama usaha (Syirkah) atau upah (ujrah) dengan masyarakat. Ketika keperluan masyarakat adalah untuk modal usaha, maka BMT masjid dapat menawarkan bentuk kerjasama usaha (Syirkah). Sedangkan ketika keperluan masyarakat adalah untuk konsumtif seperti pembelian barang maka BMT masjid dapat menawarkan margin atau upah (Ujrah).

Basis masjid ini akan sangat efektif untuk menggantikan sistem rente, dimana lokasi masjid merupakan lokasi yang paling mudah dijangkau oleh masyarakat Desa Panulisan Timur karena setidaknya terdapat 3 masjid dalam 1 dusun, sehingga ketersediaan pinjaman ada setiap hari dan pencairan dananya pun bisa pada hari peminjaman. Selain itu, ketika masjid difungsikan dalam hal mengelola perekonomian masyarakat maka secara tidak langsung masjid akan mengedukasi sistem ekonomi yang sesuai dengan Al-Quran dan Hadits kepada masyarakat.

Peran masjid ini perlu didukung juga dengan adanya lembaga formal lain seperti bank syariah yang mendukung terlaksananya BMT disetiap masjid. Bank syariah bisa menjadi partner BMT masjid dalam hal penyediaan dana yang tidak mampu ditangani oleh infaq masjid. Selain itu bank syariah dapat menjadikan masjid sebagai kantor cabang pembantu disetiap desa, sehingga percepatan persebaran sistem keuangan Islam dapat dilakukan secara massive.

Disamping pengaktifan fungsi masjid, perlu adanya peningkatan pemahaman masyarakat terkait larangan transaksi rente dan solusi sistem ekonomi Islam. Hal tersebut merupakan peran dari ulama setempat dan juga kalangan akademisi yang konsen terhadap ekonomi syariah. Ulama dan akademisi harus bekerjasama untuk memberikan pemahaman tentang keharaman riba kepada masyarakat. Ketika dalam internal masyarakat sudah memahami bahwa penggunaan transaksi rente tersebut merupakan sebuah transaksi yang dilarang maka secara langsung masyarakat akan tertahan untuk melakukan transaksi rente tersebut.

Disisi lain kalangan akademisi harus mendukung penyebaran ekonomi Islam melalui ranah pendidikan formal. Pemahaman tentang transaksi-transaksi yang sesuai dengan syariah harus mulai ditanamkan sejak dini. Ketika dalam pendidikan formal sudah diberikan pemahaman tentang transaksi yang sesuai dengan syariah, maka masyarakat akan mudah beralih ke sistem yang sesuai dengan Al-Quran dan Hadits.

\section{Simpulan dan Saran}

\subsection{Simpulan}

Kesimpulan yang diperoleh dari hasil penelitian ini adalah sistem rente dapat masuk ke sistem ekonomi masyarakat Desa Panulisan Timur Kecamatan Dayeuhluhur Kabupaten Cilacap melalui proses aktif dan pasif, kedua proses ini menjadi sebuah siklus yang terus terjadi sampai ada sebuah sistem baru yang dapat memotong keberlangsungan siklus masuk dan bertahannya sistem rente tersebut. 
Rentenir di Desa Panulisan Timur Kecamatan Dayeuhluhur Kabupaten Cilacap, melakukan pendekatan secara personal dan kontinu untuk menjalin kerjasama pinjaman dengan masyarakat. Syarat yang mudah, ketersediaan dana setiap hari, pencairan dana cepat dan akses mudah menjadi salahsatu nilai lebih yang dimiliki oleh sistem rente di Desa sehingga adanya praktik rente ini mampu diterima dan bertahan di masyarakat Desa Panulisan Timur Kecamatan Dayeuhluhur Kabupaten Cilacap.

Keunggulan yang diberikan oleh sistem rente seharusnya dapat dicontoh oleh Lembaga Keuangan Mikro (LKM) lain khususnya Lembaga Keuangan Mikro Syariah (LKMS). Syarat yang mudah, ketersediaan dana setiap hari, pencairan dana cepat dan akses yang mudah harus juga diberikan oleh LKMS. LKMS harus mampu menggantikan sistem rente yang tidak sesuai dengan syariah. Cara yang mungkin bisa dilakukan adalah dengan mengimbangi kemudahan yang diberikan kepada nasabah seperti yang dilakukan oleh sistem rente.

LKMS harus mampu memahami faktor-faktor internal dan eksternal dari setiap masyarakat agar mampu menggantikan sistem rente. LKMS harus mampu memberikan fasilitas memenuhi kebutuhan uang cash yang mendesak dan memberikan bantuan modal dan tentunya dengan menggunakan sistem yang sesuai dengan syariah. Faktor-faktor eksternal seperti syarat yang mudah, ketersediaan dana setiap hari, pencairan dana cepat dan akses yang mudah harus mampu diberikan oleh LKMS agar masyarakat mau beralih kepada sistem syariah. Dalam teori The Triangle of Microfinance diketahui bahwa syarat LKM mampu bersaing adalah dengan terpenuhinya tiga katagori outreach, financial sustainability dan impact. Pada kasus di Desa Panulisan Timur, sistem rente hanya mampu melakukan dua kategori pertama yaitu outreach dan financial sustainability sedangkan impact terhadap lingkungan sekitar masih belum dapat dicapai oleh sistem rente. Pada kesempatan ini sistem ekonomi syariah yang dilakukan oleh LKMS harus mampu menggantikan sistem rente yang terjadi di Desa Panulisan Timur. Ketika LKMS mampu mengadopsi keunggulan yang dimiliki oleh sistem rente, maka katagori yang ketiga yaitu impact pasti dapat terwujud. Sehingga LKMS akan mampu menjadi Lembaga Keuangan Mikro yang mampu bersaing dan bertahan di masyarakat, khususnya masyarakat Desa Panulisan Timur Kecamatan Dayeuhluhur Kabupaten Cilacap.

\subsection{Saran}

Berdasarkan hasil penelitian, perlu adanya penelitian lanjutan yang mampu meneliti sistem rentenir dengan skala yang lebih besar, agar hasil dari penelitian mampu memberikan gambaran kondisi sistem rente di Indonesia sehingga ketika hasil dari penelitian sudah mampu mencerminkan kondisi Indonesia maka kebijakan yang berkaitan dengan pengembangan sistem ekonomi Islam di Indonesia dapat bersifat umum dan mampu diterapkan disemua wilayah.

\section{Daftar Pustaka}

[AOKI] Alkitab Online Kristiani Indonesia. 2013. Bunga uang atau riba. [internet]. [diunduh 2014 Mar 7]. Tersedia pada: http://www.jesoes.com

[Kemenag RI] Kementrian Agama Republik Indonesia. 2002. Al Quran dan Terjemahannya. Jakarta (ID): Darus Sunnah.

Amalia E. 2010. Sejarah Pemikiran Ekonomi Islam. Depok (ID): Gramata Publishing.

Ananda. 2011. Analisis Perkembangan Usaha Mikro dan Kecil Setelah Memperoleh Pembiayaan Mudharabah dari BMT At-Taqwa Halmahera di Kota Semarang [Skripsi]. Semarang (ID): Universitas Diponegoro.

Harahap A. 2012. Sejarah Kehidupan Sehari-hari Komunitas India di Medan awal abad 20 - tahun 1950an [Tesis]. Jogjakarta (ID): Universitas Gajah Mada. 
Juanda B. 2009. Metodologi Penelitian Ekonomi dan Bisnis. Bogor (ID): IPB Press.

Juniarto A. 2013. Motivasi dan Perilaku Masyarakat Sekitar Hutan dalam Pengelolaan Kawasan Hutan (Kasus Kawasan Hutan Sekitar Desa Gunung Sari di Kecamatan Pamijahan, Kabupaten Bogor) [Skripsi]. Bogor (ID): Institut Pertanian Bogor.

Kartono DT. 2004. Pasar Modal Tradisional (Analisis Sosiologi Ekonomi terhadap Rentenir) [jurnal]. Surakarta (ID): Universitas Sebelas Maret.

Miles MB, Huberman AM. 1992. Analisis Data Kualitatif. Rohidi TR, penerjemah. Depok (ID): UI Press. Terjemahan dari: Qualitative Data Analysis.

Oktavi S. 2009. Analisis Faktor-Faktor yang Memengaruhi Pengambilan Pembiayan dan Efektivitas Pembiayaan Usaha Kecil Pada Lembaga Keuangan Mikro Syariah (Studi Kasus: KJKS BMT Bina Umat Sejahtera, Lasem, Jawa Tengah) [Skripsi]. Bogor (ID): Institut Pertanian Bogor.

Puspitasari H. 2012. Akses UMKM Terhadap Pembiayaan Mikro Syariah dan Dampaknya Terhadap Perkembangan Usaha (Kasus: BMT Tadbiirul Ummah, Kabupaten Bogor) [Skripsi]. Bogor (ID): Institut Pertanian Bogor.

Supriatna A. 2003. Aksesibilitas Petani Kecil Pada Sumber Kredit Pertanian Di Tingkat Desa: Studi Kasus Petani Padi Di Nusa Tenggara Barat. Nusa Tenggara Barat (ID).

Widiyanto, Mutamimah, Hendar. 2011. Effectiveness of Qard Al-Hasan Financing As a Poverty Alleviation Model. Economic Journal of Emerging Market.

Zeller M, Meyer RL. 2002. The Triangle of Microfinance: Financial Sustainability, Outreach, and Impact. IFPRI International Food Policy Research Institute. 